Cite as: Haig JA, Connolly RM, Hughes JM (2013) Sympatric seagrass shrimp show similar structure and selection along the seashore: a comparison of two cryptic Phycomenes

zostericola lineages. Marine Ecology 34:30-42

\title{
Sympatric seagrass shrimp show similar structure and selection along the seashore: a comparison of two cryptic Phycomenes zostericola lineages
}

\author{
AUTHORS: Jodie A. Haig ${ }^{1}$, Rod M. Connolly ${ }^{2}$ and Jane M. Hughes ${ }^{1}$ \\ 1. Australian Rivers Institute, Griffith School of Environment, Griffith University, Nathan campus, \\ Brisbane, Qld 4111, Australia. \\ Corresponding author: Jodie Haig, Email: jodiehaig@gmail.com
}

2. Australian Rivers Institute, Griffith School of Environment, Gold Coast campus, Griffith University, Qld, 4222, Australia

\begin{abstract}
Small crustaceans are diverse and abundant in seagrass habitats and provide many ecological services. Further information is needed about their long and short-term response to habitat fragmentation and loss. Shrimp were sampled from coastal seagrasses: latitudes $9^{\circ}-27^{\circ} \mathrm{S}$ (Torres Strait to Moreton Bay, Queensland, Australia) and longitudes $141^{\circ}-153^{\circ} \mathrm{E}$ (Weipa to Moreton Bay, Queensland, Australia). The seagrass shrimp Phycomenes zostericola (Caridea: Decapoda) underwent phylogeographic analysis using mitochondrial and nuclear sequence data. Lineage relationships were investigated and two deeply divergent, cryptic and sympatric lineages of Phycomenes zostericola were discovered in northern samples. The two lineages display vastly different demographic histories in spite of similar overall phylogeographic patterns. The two lineages appear to be in secondary contact with each other, detailing independent histories of sea level change, long distance colonisation and habitat fragmentation. Their regional structure is evidence that the potential for dispersal is only realised under specific environmental conditions. Nuclear data, used to determine reproductive status between lineages, instead displayed a non-random latitudinal geographic distribution suggesting directional selection, possibly in response to ocean temperatures. The differences between the two deeply divergent lineages highlight the importance of understanding variability among cryptic taxa and their response to habitat change.
\end{abstract}

Keywords Caridea, cryptic species, cytochrome oxidase I, Decapoda, myosin heavy chain, phylogeography. 
Cite as: Haig JA, Connolly RM, Hughes JM (2013) Sympatric seagrass shrimp show similar structure and selection along the seashore: a comparison of two cryptic Phycomenes zostericola lineages. Marine Ecology 34:30-42

\section{PROBLEM}

Caridean shrimp are a diverse and abundant component of seagrass fauna (De Grave 1999). Seagrass shrimp enhance the nursery function of seagrass habitats, and have a valuable indirect contribution to commercial fisheries, as they are an abundant and palatable food source for juvenile fisheries species (Heck et al. 2003). Although phylogeographic studies on caridean shrimp are not uncommon, most in Australia focus on freshwater species (Hughes et al. 1995; Hurwood and Hughes 2001). Broad scale connectivity studies on small marine shrimp were undertaken in South Africa (Teske et al. 2007). However, little other phylogeographic research has been done on shrimp in seagrass systems. Seagrass habitats are becoming increasingly fragmented and lost due to anthropogenic influences (Orth et al. 2006; Connolly 2009). As this vital habitat becomes lost it becomes ever more urgent that we understand how seagrass fauna responds to change, in general and specifically for individual species. These questions are further complicated by the presence of cryptic species and the similar or divergent responses that they may have to environmental change.

Cryptic species are not rare in the sea; they are common among crustaceans and can be found at almost any depth and at all latitudes (Knowlton 1993) in the presence or absence of obvious biogeographical boundaries (Hellberg 1998; Knowlton and Weigt 1998; Barber et al. 2000; Mathews et al. 2002). To effectively manage marine biodiversity it is vital that we identify cryptic diversity. It is also important to understand the environmental and biological drivers behind new diversity. Divergence between species may be accelerated by selection, which can operate over very short temporal scales (see, Hilbish 1985) and small spatial scales; ranging from kilometres for the copepod Tigriopus californicus (Burton 1997) to meters for the intertidal gastropod Littorina saxatilis (Wilding et al. 2001).

Cryptic species or species with similar life histories, exposed to the same long-term extrinsic barriers to gene flow, should display similar intraspecific phylogenetic structuring in a geographically concordant manner (Avise et al. 1987; Avise 2000). This is true, for example, in Torres Strait, where a shallow stretch of sea extends between Australia and Papua New Guinea. Fluctuating sea levels here sundered populations east and west by the repeated formation of a land bridge on the Sahul shelf (Galloway and Kemp 1981). Evidence of divergence can be found in multiple marine species either side of the Torres Strait (Lavery et al. 1996; Benzie et al. 2002; Crandall et al. 2008).

Phycomenes zostericola are abundant, have a broad coastal distribution (northern Western Australia, Northern Territory, Queensland and New South Wales), and are closely associated with their seagrass habitat (Bruce 2008; Haig et al. 2010); they thus provide an ideal study organism to explore broad scale patterns of connectivity among seagrass-associated fauna. Initial analyses of $P$. zostericola populations revealed two deeply divergent lineages. Of the two cryptic lineages, lineage one (hereafter referred to as L1) displays a complex evolutionary history shaped by fluctuating sea levels and available refugia along a variable continental shelf (Haig et al. 2010). The phylogeographic patterns of lineage two (L2) and the evolutionary relationship between the two lineages are the focus here. 
Cite as: Haig JA, Connolly RM, Hughes JM (2013) Sympatric seagrass shrimp show similar structure and selection along the seashore: a comparison of two cryptic Phycomenes zostericola lineages. Marine Ecology 34:30-42

This paper reports the discovery and comparison of two mitochondrial lineages of $P$. zostericola. We assess both lineages for morphological differences and used nuclear markers to support the hypothesis that the two lineages were in reproductive isolation. Using coalescent analysis and comparative phylogeography we determined variations in demographic response to sea level change and coastal habitat among cryptic populations of seagrass-associated caridean shrimp.

\section{MATERIALS AND METHODS}

\section{Sampling strategy}

Sample sites were chosen to encompass the range of the species P. zostericola in Queensland and were designed to test genetic breaks along the Queensland coastline (see Haig et al. 2010). Specimens of $P$. zostericola were obtained from 19 of the 26 seagrass habitats sampled along the Queensland coastline. The smallest distance between adjacent sites where L2 was caught was $25 \mathrm{~km}$ (Ugar Island to Erub Island) and the greatest was 1,080 km (Torres Strait to Townsville). All sites were $<100 \mathrm{~m}$ from shore and $<2 \mathrm{~m}$ deep at low tide.

\section{Morphological examination}

A caridean taxonomic key (Wadley 1978) and the taxonomic description of P. zostericola (Bruce 2008) were used to identify typical morphological identifiers between lineages. All morphological traits were compared between several individuals from each lineage from across the sampled range. To confirm our findings we also provided several individuals from each lineage across the sampled range to Dr. A.J. Bruce, a caridean taxonomic specialist from the Queensland Museum.

\section{DNA extraction}

The distal abdominal segments of shrimp were sectioned to avoid the potential contamination by food contents partially digested in the foregut. Total genomic DNA was extracted using a modification of the cetyl trimethyl ammonium bromide (CTAB) / phenol-chloroform DNA extraction protocol (Doyle and Doyle 1987) and stored in $50 \mu \mathrm{l}$ of water at $<4{ }^{\circ} \mathrm{C}$.

\section{Polymerase chain reaction amplification and sequencing}

An $\sim 800$ bp fragment of the mitochondrial cytochrome c oxidase subunit I (COI) gene, a $\sim 300 \mathrm{bp}$ fragment of the Histone 3 gene and $\sim 600 \mathrm{bp}$ fragment of the nuclear coding gene myosin heavy chain (MyHC) was amplified by polymerase chain reaction (PCR). COI and $\mathrm{MyHC}$ loci were chosen due to the high level of intraspecific diversity found in other crustaceans (Williams et al. 2002; Cook et al. 2008), and H3 is a highly conserved nuclear gene which was used to investigate interspecies diversity. PCRs were run in an Eppendorf Mastercycler Gradient or an Applied Biosystems Geneamp PCR System 2700 and 9700 (Applied Biosystems, Mulgrave, Victoria, Australia). PCR conditions for the amplification of COI can be found in Haig et al. (2010). PCRs contained approximately $40 \mathrm{ng}$ of template DNA, 0.5 of each 1M primer MyHC1124 forward (5' 5'AAG CTC GAG TCT GAC ATC 
Cite as: Haig JA, Connolly RM, Hughes JM (2013) Sympatric seagrass shrimp show similar structure and selection along the seashore: a comparison of two cryptic Phycomenes

zostericola lineages. Marine Ecology 34:30-42

A3' and MyHC1806 R 5'GCA CTT CCT CAG GTT CTT CT3' (Williams et al. 2002), 0.5 $\mathrm{mM}$ dNTP (Astral Scientific, Caringbah, NSW, Australia), $2 \mathrm{mM} \mathrm{MgCl} 2,1 \mu \mathrm{l}$ of $10 \mathrm{x}$ polymerase reaction buffer and 0.02 units of Taq polymerase (Fisher Biotech, Subiaco, WA, Australia) adjusted to a final volume of $10 \mu \mathrm{l}$. PCR for MyHC followed the thermo-cycling profile of: 5 minutes at $94{ }^{\circ} \mathrm{C} ; 40$ cycles of 30 seconds at $94{ }^{\circ} \mathrm{C}, 30$ seconds at $60{ }^{\circ} \mathrm{C}$ and 30 seconds at $72{ }^{\circ} \mathrm{C}$ followed by an extension step of 5 minutes at $72{ }^{\circ} \mathrm{C}$ and a final hold at $4{ }^{\circ} \mathrm{C}$. PCR success was visualised under UV light by running product through a $1 \%$ agarose gel containing Ethidium bromide. All PCR products were run alongside a $1 \mathrm{~kb}$ DNA size ladder (Invitrogen). PCR product was purified with the exonuclease I-shrimp alkaline phosphatase (exo-sap) method, using $7 \mu \mathrm{l}$ PCR product, $1 \mu \mathrm{l}$ shrimp alkaline phosphatase (Promega, Fitchburg, WI, USA), and $0.25 \mu \mathrm{l}$ exonuclease I (Fermentas, Burlington, ON, Canada) and a two-step thermal cycling profile of: 35 minutes at $35^{\circ} \mathrm{C}$ and 20 minutes at $80{ }^{\circ} \mathrm{C}$. Sequencing reactions contained $1 \mu \mathrm{l}$ purified product, $1 \mu \mathrm{l}$ forward primer, $0.5 \mu 1$ BigDye v1.1 (Applied Biosystems), and $2 \mu \mathrm{l}$ BigDye 5x sequencing buffer (Applied Biosystems) and $5.5 \mu \mathrm{l}$ of distilled water at the following thermal cycling profile: 1 minute at $96^{\circ} \mathrm{C} ; 30$ cycles of $10 \mathrm{~s}$ at $96{ }^{\circ} \mathrm{C}, 5 \mathrm{~s}$ at $50{ }^{\circ} \mathrm{C}$, and 4 minutes at $60{ }^{\circ} \mathrm{C}$; and a hold at $4{ }^{\circ} \mathrm{C}$. Sequencing was conducted on a 3130xl Capillary Electrophoresis Genetic Analyser (Applied Biosystems). Sequences were aligned and edited using Sequencher version 4.1.2 (Gene Codes Corporation, Ann Abor, MI, USA). The COI and MyHC datasets were aligned at default settings. No gaps occurred in any alignments. As crustaceans may contain pseudogenes of mitochondrial fragments (Song et al. 2008), all mitochondrial sequences were transformed into codons and scanned for internal stop codons.

\section{Other nuclear loci trialled}

The amplification of multiple anonymous loci and also nuclear genes: 28S (Mitsuhashi et al. 2007) and Histone 3 (Porter et al. 2005) were trialled on several individuals from varied locations and both lineages. All nuclear loci failed to yield any variable sites within or between the two divergent lineages (data not shown). Elongation factor $\alpha 1$ (Williams et al. 2001) and the internal transcribe spacer gene (ITS) (Ji et al. 2003) resulted in multiple bands and messy product and further, due to ITS existing in multiple copies within individuals, both genes were deemed unsuitable for this study.

\section{Mitochondrial COI likelihood methods}

Phylogenetic and molecular evolutionary analyses were conducted using MEGA version 4 (Tamura et al. 2007). The net mean genetic distance between the 159 samples (P. zostericola L1 $n=127 ;$. zostericola L2 $n=32$ ) used a bootstrap value of 1,000 and a maximum composite likelihood model. Outputs provided a divergence estimate and standard error. The divergence estimate was calculated with a $1.4 \% \mathrm{Myr}^{-1}$ evolutionary rate for the crustacean mitochondrial gene COI (Knowlton and Weigt 1998). A maximum parsimony phylogeny was then inferred from 1,000 replicates and is taken to represent the evolutionary relationship between ten individuals from both lineages. The maximum likelihood tree was obtained using RAXML (Stamatakis et al. 2005; Stamatakis 2006) via the CIPRES web portal version 1.15 
Cite as: Haig JA, Connolly RM, Hughes JM (2013) Sympatric seagrass shrimp show similar structure and selection along the seashore: a comparison of two cryptic Phycomenes zostericola lineages. Marine Ecology 34:30-42

(Miller et al. 2009) with bootstrap replicates of 1,000 (Stamatakis et al. 2008). Trees were viewed and edited in the program DENDROSCOPE v2.3 (Huson et al. 2007).

\section{Population analyses}

No internal stop codons were found permitting all fragments to be used in data analyses. For the COI dataset: estimates of haplotype and nucleotide diversity were calculated using DNASP 4.0 (Rozas et al. 2003). Pair-wise comparisons of $F_{\mathrm{ST}}$ and $\Phi_{\mathrm{ST}}$ values were calculated in Arlequin 3.1 using 1,000 bootstrap repetitions (Excoffier et al. 2005) and a modified false discovery rate (FDR) correction (Narum 2006) where alpha equalled 0.05 and probability values less than 0.0114 were considered significant. A Mantel test (1,000 permutations) was used to test for isolation-by-distance. The input matrix compared distance values (straight line distances conforming to the shape of the coastline in $\mathrm{km}$ ) against Slatkin's linearized $\Phi_{\mathrm{ST}}$ values. Geographical structure was analysed using a hierarchical analysis of molecular variance (Excoffier et al.). The significance of the following fixation indices ( $\Phi_{\mathrm{ST}}, \Phi_{\mathrm{SC}}$ and $\left.\Phi_{\mathrm{CT}}\right)$ were tested using permutation procedures outlined in Excoffier et al. (1992).

Populations were grouped to test for the significant partitioning of among group genetic variation $\left(\Phi_{\mathrm{CT}}\right.$ ) based on the hypothesis that $P$. zostericola L1 and L2 are morphologically identical and are probably similar in biology and habitat choice so were expected to display similar phylogeographic patterns. $P$. zostericola L1 show divergence between Torres Strait Islands and Queensland populations (Haig et al. 2010); so, L2 populations were expected to display a similar structure. The geographic structure was also investigated using a simulated annealing approach in SAMOVA (spatial analysis of molecular variance, Dupanloup et al. 2002), which was used to partition populations that are geographically similar and maximally differentiated (thus providing the highest $\Phi_{\mathrm{CT}}$ values). SAMOVA was run for 10,000 iterations for $K=2$ to 5 using 100 initial conditions.

\section{Haplotype network and nested clade phylogeographic analysis (NCPA)}

Haplotype networks were constructed using statistical parsimony (95\% probability cut-off) in TCS software, version 1.21 (Clement et al. 2000). Several ambiguous loops were resolved using some predictions from coalescent theory before clades were nested (Templeton and Sing 1993; Posada and Crandall 2001). Clades were nested by hand using rules from Templeton et al. (1987), Templeton \& Sing (1993) and Templeton et al. (1995). Input files for the geographical locations and nested haplotype design were run by GEODIS 2.5 (Posada et al. 2000). The output was assessed using the latest version of the GEODIS inference key (December 15, 2008) to infer biological explanations for clades found to display significant structure. Although nested clade phylogeographic analysis has been the subject of recent criticism (Petit 2008, and references therein) it remains a valuable phylogeographic tool (Templeton 2008), particularly when inferences are corroborated by independent analyses.

\section{Population demographic expansion}


Cite as: Haig JA, Connolly RM, Hughes JM (2013) Sympatric seagrass shrimp show similar structure and selection along the seashore: a comparison of two cryptic Phycomenes zostericola lineages. Marine Ecology 34:30-42

Tajima's $D$ (Tajima 1989) and Fu's $F_{\mathrm{S}}(\mathrm{Fu} 1997)$ tests were used to determine if sequence variation was consistent with predictions under the neutral model. Tajima's $D$ compares two estimates of diversity that should be the same under neutrality. Fu's $F_{\mathrm{S}}$ is more sensitive to demographic expansion; it is based on the haplotype frequency distribution conditional to the genetic diversity of the sample; negative values in both analyses result from an excess of substitutions relative to expectations for a constant-sized population and may be interpreted as evidence for recent population expansion. P. zostericola L2 haplotypes were nested into four clade levels; to test for clade demographic expansion the two clades from level three were grouped for neutrality tests and mismatch analysis. Parameters of the mismatch distributions, with $95 \%$ confidence intervals, were calculated using a generalised least-square approach (Schneider and Excoffier 1999; Excoffier 2004) with the addition of Harpending's raggedness index (Harpending 1994). Time as scaled by mutation (tau) and time (ka) was calculated using a 1.4\% $\mathrm{Myr}^{-1}$ mutation rate (Knowlton and Weigt 1998).

\section{Coalescent analysis}

The hypothesis that the two lineages and the populations within them may have each experienced isolation and vicariance due to the last glacial maximum (LGM) was tested using coalescent analysis on the mitochondrial dataset. Population divergence times $(t)$, effective population size $(\mathrm{Ne})$ and the time to most recent common ancestor (TMRCA) were calculated using the IM program (Hey and Nielsen 2004) for both P. zostericola lineages and also between Queensland and Torres Strait populations belonging to L2. As there was an absence of genetic structure between populations within both Queensland and Torres Strait for L2, populations were grouped into region. The $t$ value was estimated between each pair of adjacent sample locations, as well as the $\mathrm{Ne}$ value for each. Preliminary analyses using wide intervals were used to determine prior distributions. Metropolis coupling was used to swap between 10 and 20 chains with heating of all chains set at $\mathrm{g} 1=0.8, \mathrm{~g} 2=0.9$ to ensure the effective sampling of parameter space. All runs were executed for three million updates. Posterior distributions (including 90\% credibility intervals) provided estimates of population divergence time $(t)$, contemporary and ancestral theta $\left(\theta_{1 \text { or } 2}\right.$ and $\left.\theta_{\mathrm{A}}\right)$. To convert divergence time into years, a sequence divergence rate of $1.4 \% \mathrm{Myr}^{-1}$ for COI was used, which is the calibrated evolutionary rate for COI in caridean shrimp (Knowlton and Weigt 1998; Morrison et al. 2004) and with a generation time of one year, with generation time taken to mean the mid point between becoming a reproductive individual and dying (A.J. Bruce, Queensland Museum, pers. comm.). Runs were repeated for each pair-wise comparison of adjacent populations to ensure parameter estimates were consistent. 
Cite as: Haig JA, Connolly RM, Hughes JM (2013) Sympatric seagrass shrimp show similar structure and selection along the seashore: a comparison of two cryptic Phycomenes zostericola lineages. Marine Ecology 34:30-42

\section{RESULTS}

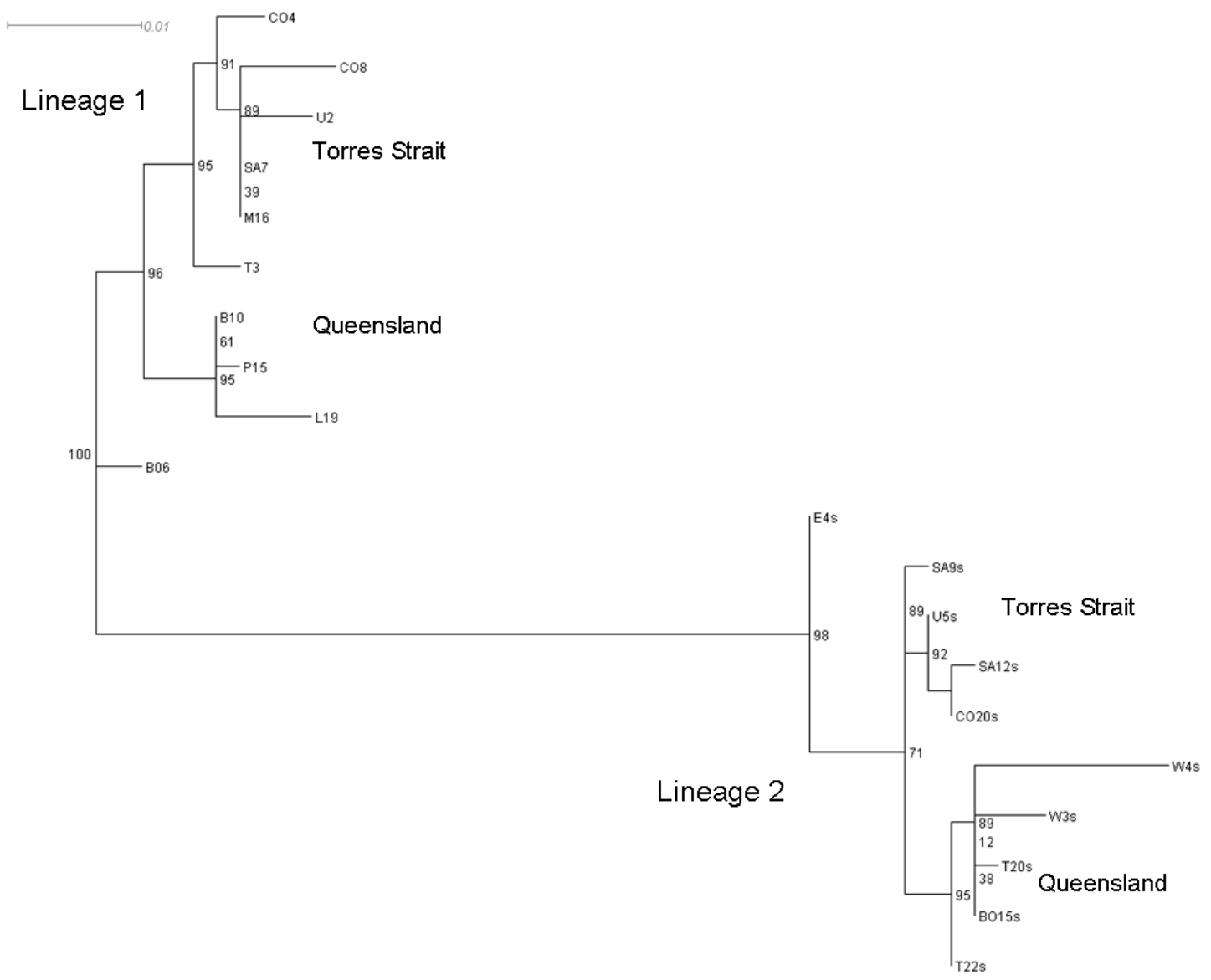

Figure 1. The evolutionary history of two Phycomenes zostericola lineages inferred from a maximum likelihood tree using RAXML (Stamatakis et al. 2005; Stamatakis 2006) via the CIPRES web portal version 1.15 (Miller et al. 2009) with bootstrap replicates of 1,000 (Stamatakis et al. 2008). Trees were viewed and edited in the program DENDROSCOPE V2.3 (Huson et al. 2007). Scale bar indicates percentage of nucleotide divergence. Numbers on tree indicate bootstrap values. Torres Strait: CO, Coconut Island; E, Erub Island; M, Moa Island; SA, Saibai Island; U, Ugar Island. Queensland (from north to south): W, Weipa; T, Townsville; P, Pumicestone passage; L, Loders Creek. Small s after site code indicates L2.

\section{Morphology}

Individuals from the two lineages were found to be morphologically indistinguishable from the P. zostericola type material described in Bruce (2008).

\section{Sequencing results}

Sequencing usually resulted in good quality sequences that were easy to align. A total of 279 individual specimens of $P$. zostericola L1 from 19 of the 27 sampled locations and 58 individual specimens of $P$. zostericola L2 from 10 of the sites where L1 co-occurred underwent molecular examination. All individuals from both lineages were analyzed for a 590-bp segment of the mitochondrial gene COI. Similarly, sequencing of the nuclear gene MyHC resulted in a 610-bp segment and contained a single nucleotide polymorphism (SNP) at position 233 in both lineages (Fig. 2). Aligning P. zostericola MyHC sequences with other palaemonid specimens, and also Drosophila melanogaster and Homarus gammarus MyHC 
Cite as: Haig JA, Connolly RM, Hughes JM (2013) Sympatric seagrass shrimp show similar structure and selection along the seashore: a comparison of two cryptic Phycomenes zostericola lineages. Marine Ecology 34:30-42

sequences available from GenBank did not yield any useful information on codon positioning and hence we could not determine the non/synonymous nature of the SNP. The following sequences were submitted to GenBank (L1 COI accession numbers GU576176-GU576454; L2 COI; L1 and L2 MyHC and H3 accession numbers JN82236-JN82263).

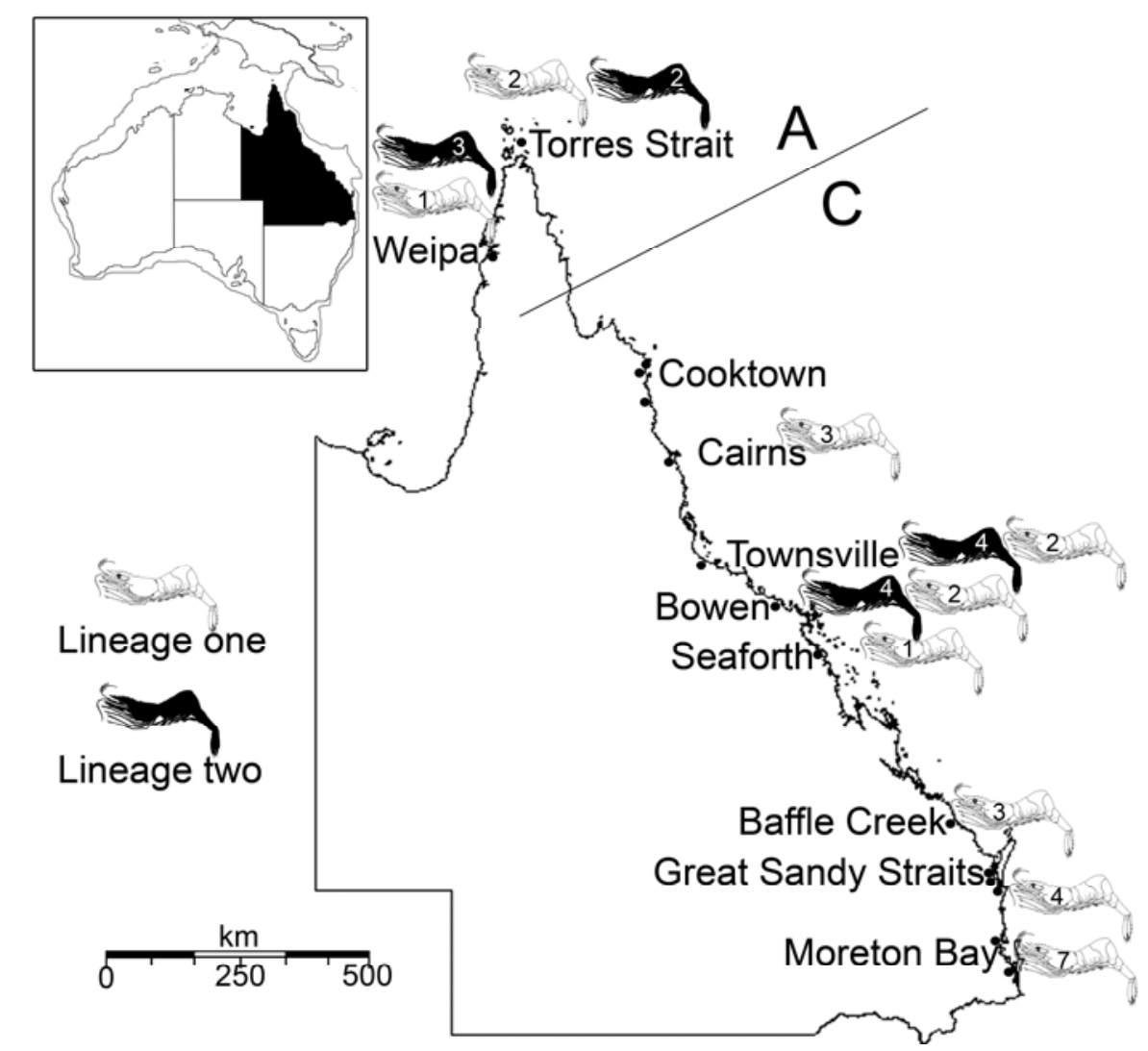

Figure 2. A map of Queensland, Australia displaying regions where each mitochondrial lineage of Phycomenes zostericola was sampled for the nuclear gene Myosin Heavy Chain (MyHC). Numbers on shrimp indicate total individuals sampled at that location. A line indicates the geographical separation the two MyHC alleles. A single nucleotide polymorphism in the MyHC gene occurs as an adenine (A) in northern individuals or a cytosine (C) in southern individuals. Inset map of Australia shows northern orientation (arrow) and the states where P. zostericola have been caught (Bruce 2008): WA, Western Australia; NT, Northern Territory; QLD, Queensland; NSW, New South Wales.

\section{Deep divergence of the mitochondrial gene $\mathrm{COI}$}

Divergence between the two $P$. zostericola lineages was estimated at 5.6\% ( $\mathrm{SE} \pm 1 \%$ ) using a maximum composite likelihood model. The grouping of two lineages is supported by $100 \%$ bootstrap support and within each lineage a north - south grouping was supported by $96 \%$ (L1) and 71\% (L2) bootstrap values (Fig. 1). Using a 1.4\% $\mathrm{Myr}^{-1}$ divergence rate (Knowlton and Weigt 1998) the two $P$. zostericola lineages were calculated to have diverged during the mid Pliocene; $3.92 \mathrm{Ma}(\mathrm{SE} \pm 0.7 \mathrm{myr})$.

\section{Population analyses}


Cite as: Haig JA, Connolly RM, Hughes JM (2013) Sympatric seagrass shrimp show similar structure and selection along the seashore: a comparison of two cryptic Phycomenes zostericola lineages. Marine Ecology 34:30-42

A full report of the genetic structure of L1 populations can be found in Haig et al. (2010). A high level of diversity and regional structuring was observed for L2 populations. Of the 58 L2 sequences used in population analyses, 32 haplotypes, with 40 segregating sites and 16 parsimony informative sites were found in the 590-bp long COI segment. Site haplotype diversity ranged from 0 to 1 (Table 2). No correlative relationships were found between nucleotide diversity and geographic location to support a range expansion hypothesis. In 45 pair-wise population comparisons $23 F_{\text {ST }}$ values were significant (Table 2); 15 pair-wise $F_{\text {ST }}$ comparisons remained significant under false discovery rate (FDR) correction (Narum 2006). Significant structure was observed between Torres Strait islands and Queensland populations (Table 2). The reduction in significant pair-wise comparisons after the FDR correction did not change any overall patterns of genetic differentiation. An isolation by distance effect was detected using Mantel test $(\mathrm{r}=0.68 ; P \leq 0.002)$. A significant proportion of the genetic variance observed among populations was significant regardless of hierarchy (Table 3). Grouping Weipa samples with Torres Strait samples did not yield a significant $\Phi_{\mathrm{CT}}$ value. Genetic structure between Torres Strait Islands and Queensland was evident in all SAMOVA partitions (Table 3). The largest $\Phi_{\mathrm{CT}}$ value observed using SAMOVA was for $K=2$. Little change in $\Phi_{\text {ST }}$ was observed between $K=2$ to $K=5$ (Table 3).

Table 1. Regions in Queensland where Phycomenes zostericola were caught and number of individuals belonging to each mitochondrial COI lineage. Latitude and Longitude indicate either a single or range of sampling locations.

\begin{tabular}{|c|c|c|c|c|}
\hline Sampled location & Latitude & Longitude & Lineage One $n$ & Lineage Two $n$ \\
\hline Weipa & $12^{\circ} 40^{\prime} 32.44^{\prime \prime} \mathrm{S}$ & $141^{\circ} 52^{\prime} 44.73^{\prime \prime} \mathrm{E}$ & 13 & 11 \\
\hline \multirow[t]{3}{*}{ Torres Strait islands } & $10^{\circ} 35^{\prime} 10.04$ 'S & $142^{\circ} 13^{\prime} 18.03^{\prime \prime} \mathrm{E}$ & \multirow[t]{3}{*}{69} & \multirow[t]{3}{*}{34} \\
\hline & $09^{\circ} 22^{\prime} 18.46^{\prime \prime} \mathrm{S}$ & $142^{\circ} 37^{\prime} 02.14^{\prime \prime} \mathrm{E}$ & & \\
\hline & $09^{\circ} 36^{\prime} 38.88^{\prime \prime} S$ & $143^{\circ} 46^{\prime} 25.10^{\prime \prime} \mathrm{E}$ & & \\
\hline \multirow[t]{2}{*}{ Cairns / Cooktown } & $15^{\circ} 27^{\prime} 18.88^{\prime \prime} \mathrm{S}$ & $145^{\circ} 13^{\prime} 43.27$ ' E & \multirow[t]{2}{*}{22} & \multirow[t]{2}{*}{0} \\
\hline & $16^{\circ} 54^{\prime} 00.77^{\prime \prime S}$ & $142^{\circ} 45^{\prime} 27.20^{\prime \prime} \mathrm{E}$ & & \\
\hline Townsville & $19^{\circ} 11^{\prime} 18.25^{\prime \prime S}$ & $146^{\circ} 40^{\prime} 56.97^{\prime \prime} \mathrm{E}$ & 14 & 9 \\
\hline Bowen & $20^{\circ} 01^{\prime} 05.09^{\prime \prime S}$ & $148^{\circ} 15^{\prime} 00.21^{\prime \prime} \mathrm{E}$ & 15 & 4 \\
\hline Dingo Beach / & $20^{\circ} 05^{\prime} 17.29^{\prime \prime} \mathrm{S}$ & $148^{\circ} 25^{\prime} 51.79^{\prime \prime} \mathrm{E}$ & \multirow[t]{2}{*}{35} & \multirow[t]{2}{*}{0} \\
\hline Seaforth & $20^{\circ} 52^{\prime} 04.90^{\prime \prime} \mathrm{S}$ & $148^{\circ} 56^{\prime} 59.13^{\prime \prime} \mathrm{E}$ & & \\
\hline South East & $24^{\circ} 31^{\prime} 24.05^{\prime \prime S}$ & $152^{\circ} 02^{\prime} 57.48^{\prime \prime} \mathrm{E}$ & \multirow[t]{2}{*}{111} & \multirow[t]{2}{*}{0} \\
\hline \multirow[t]{2}{*}{ Queensland } & $27^{\circ} 57^{\prime} 13.11^{\prime \prime} \mathrm{S}$ & $153^{\circ} 24^{\prime} 38.92^{\prime \prime} \mathrm{E}$ & & \\
\hline & & TOTAL & 279 & 58 \\
\hline
\end{tabular}


Cite as: Haig JA, Connolly RM, Hughes JM (2013) Sympatric seagrass shrimp show similar structure and selection along the seashore: a comparison of two cryptic Phycomenes zostericola lineages. Marine Ecology 34:30-42

\section{Nested clade phylogeographic analysis}

The nesting of the haplotype network identified 32 haplotypes, nested into 19 one-step clades, 7 two-step clades, 3 three-step clades, and 1 four-step clade (Fig. 3). Only the total cladogram (nesting level 4 ) had a significant chi-square value $(61.80, \mathrm{P} \leq 0.001)$. Using the chain of inference it was not possible to resolve between fragmentation and isolation by distance due to inadequate sampling (data not shown). Although intermediate sites were sampled, no L2 individuals were found between Torres Straits and Townsville. The large physical distances between Torres Strait islands and Townsville was a likely contributor to the lack of resolution observed.

Table 2. Pair-wise $\mathrm{F}_{\mathrm{ST}}$ (lower matrix) and $\Phi_{\mathrm{ST}}$ (upper matrix) estimates calculated in Arlequin (Excoffier et al., 2005) for Phycomenes zostericola L2 from Queensland and Torres Strait coastal seagrass habitats. $n$, number; $n \mathrm{~h}$, number of haplotypes; h, haplotype diversity; $\pi$, nucleotide diversity; bold values are $\leq 0.05 ; F_{\mathrm{ST}}$ values with an asterisk are $\leq 0.0114$ under a FDR correction (Narum 2006).

\begin{tabular}{|c|c|c|c|c|c|c|c|c|c|c|c|c|c|c|c|}
\hline & \multicolumn{7}{|c|}{ Torres Strait Islands } & \multicolumn{3}{|c|}{ Queensland } \\
\hline & Location & $n$ & $n h$ & $\mathrm{~h}$ & $\pi$ & $\mathrm{CO}$ & SA & M & TI & $\mathrm{Y}$ & $\mathrm{E}$ & $\mathrm{U}$ & W & $\mathrm{T}$ & $\mathrm{BO}$ \\
\hline $\mathrm{CO}$ & Coconut Island & 7 & 5 & 0.857 & 0.007 & & -0.046 & 0.091 & 0.001 & 0.029 & -0.038 & 0.125 & 0.380 & 0.467 & 0.368 \\
\hline SA & Saibai Island & 8 & 7 & 0.964 & 0.005 & -0.005 & & 0.209 & 0.166 & 0.150 & -0.011 & 0.201 & 0.462 & 0.579 & 0.497 \\
\hline M & Moa Island & 4 & 1 & 0.000 & 0.000 & 0.186 & 0.230 & & 0.385 & 0.000 & 0.095 & -0.081 & 0.633 & 0.795 & 0.795 \\
\hline TI & Thursday Island & 2 & 2 & 1.000 & 0.003 & 0.104 & 0.026 & 0.724 & & 0.250 & -0.005 & 0.347 & 0.577 & 0.743 & 0.669 \\
\hline Y & Yam Island & 3 & 1 & 0.000 & 0.000 & 0.127 & 0.172 & 0.000 & 0.647 & & 0.004 & -0.154 & 0.606 & 0.776 & 0.759 \\
\hline$E$ & Erub Island & 4 & 3 & 0.833 & 0.005 & -0.129 & -0.037 & 0.167 & 0.111 & 0.077 & & 0.134 & 0.523 & 0.662 & 0.568 \\
\hline U & Ugar Island & 6 & 2 & 0.333 & 0.001 & 0.112 & 0.155 & -0.081 & 0.510 & -0.154 & 0.043 & & 0.649 & 0.799 & 0.804 \\
\hline W & Weipa & 11 & 10 & 0.982 & 0.007 & 0.067 & 0.027 & $0.360 *$ & 0.013 & $0.317 *$ & 0.078 & $0.292 *$ & & 0.007 & -0.067 \\
\hline $\mathrm{T}$ & Townsville & 9 & 8 & 0.972 & 0.003 & 0.071 & 0.032 & $0.384 *$ & 0.020 & $0.337 *$ & 0.085 & $0.311 *$ & -0.029 & & 0.091 \\
\hline $\mathrm{BO}$ & Bowen & 4 & 3 & 0.833 & 0.005 & 0.153 & 0.091 & 0.583 & 0.111 & 0.520 & 0.167 & 0.458 & -0.012 & -0.027 & \\
\hline
\end{tabular}

\section{Population demographic expansion}

Neutrality and mismatch analyses were not tested on clade level 3-2 due to its small sample size $(n=6)$. Tests of neutrality for Tajima's $D$ were significantly negative for nested clade 3 $1(-1.80, \mathrm{P} \leq 0.011)$ and clade $3-3(-2.06, \mathrm{P} \leq 0.006)$. Fu's Fs neutrality tests were significantly negative for nested clade $3-1(-6.78, \mathrm{P} \leq 0.000)$ and clade $3-3(-10.14, \mathrm{P} \leq$ 0.000 ). The parameters of the mismatch distribution for nested clade levels $3-1$ and $3-3$ could not reject a sudden population expansion model (Table 4). Population expansions estimated using tau values date well within the Pleistocene epoch: c. $16.3 \mathrm{ka}$ for nested clade level 3-1 and c. 204.5 ka for nested clade level 3-3 (Fig. 4).

\section{Coalescent analysis}

Coalescence for Torres Strait island and Queensland mainland populations was estimated to have occurred during the Pleistocene and the TMRCA existed $\sim 647$ ka (Fig. 4). Population divergence times and effective population size estimates for some locations have very broad posterior densities, which were probably due, in part, to sample size and the use of a single genetic locus. Regardless of this, Torres Strait islands and the Queensland mainland populations were estimated to have exchanged as little as one migrant every six years. Even though effective population estimates had broad posterior distributions the high numbers (in the millions) were likely true and similar to P. zostericola L1 (Haig et al. 2010). 
Cite as: Haig JA, Connolly RM, Hughes JM (2013) Sympatric seagrass shrimp show similar structure and selection along the seashore: a comparison of two cryptic Phycomenes zostericola lineages. Marine Ecology 34:30-42

Table 3. Analysis of Molecular Variance (AMOVA, above) and Spatial Analysis of Molecular Variance (SAMOVA, below) of Phycomenes zostericola L2; results calculated in Arlequin (Excoffier et al. 2005) and SAMOVA (Dupanloup et al. 2002) for mtDNA cytochrome c oxidase subunit I (COI) using haplotype frequency differences between grouped populations. Probability values shown in parentheses.

\begin{tabular}{|c|c|c|c|c|c|c|c|}
\hline & \multirow[b]{2}{*}{ Hypothesised genetic break analysed using AMOVA } & \multirow[b]{2}{*}{$\Phi_{\mathrm{CT}}$} & \multirow[b]{2}{*}{$\Phi_{\mathrm{SC}}$} & \multirow[b]{2}{*}{$\Phi_{\mathrm{ST}}$} & \multicolumn{3}{|c|}{ Percent variation (\%) } \\
\hline & & & & & $\begin{array}{l}\text { Among } \\
\text { group }\end{array}$ & $\begin{array}{l}\text { Among } \\
\text { popn within } \\
\text { group }\end{array}$ & $\begin{array}{l}\text { Within } \\
\text { Popn }\end{array}$ \\
\hline & Torres Strait / Queensland & $\begin{array}{c}0.637 \\
(<0.05)\end{array}$ & $0.021^{\mathrm{NS}}$ & $\begin{array}{c}0.637 \\
(<0.001)\end{array}$ & 63 & 1 & 36 \\
\hline$K$ & SAMOVA Population Groups & & & & & & \\
\hline 2 & $\begin{array}{l}1 \text { Weipa, Townsville, Bowen } \\
2 \text { Saibai, Coconut, Moa, Yam, Erub, Ugar, and Thursday islands }\end{array}$ & $\begin{array}{c}0.599 \\
(0.008)\end{array}$ & $0.030^{\mathrm{NS}}$ & $\begin{array}{c}0.611 \\
(0.000)\end{array}$ & 60 & 1 & 39 \\
\hline 3 & $\begin{array}{l}1 \text { Weipa, Townsville, Bowen } \\
2 \text { Thursday island } \\
3 \text { Saibai, Coconut, Moa, Yam, Erub, and Ugar islands }\end{array}$ & $\begin{array}{c}0.581 \\
(0.002)\end{array}$ & $0.03^{\mathrm{NS}}$ & $\begin{array}{c}0.594 \\
(0.000)\end{array}$ & 58 & 1 & 40 \\
\hline 4 & $\begin{array}{l}1 \text { Townsville, Weipa } \\
2 \text { Bowen } \\
3 \text { Thursday Is. } \\
4 \text { Saibai, Coconut, Moa, Yam, Erub and Ugar islands }\end{array}$ & $\begin{array}{c}0.559 \\
(0.002)\end{array}$ & $0.032^{\mathrm{NS}}$ & $\begin{array}{c}0.573 \\
(0.000)\end{array}$ & 56 & 1 & 43 \\
\hline 5 & $\begin{array}{l}1 \text { Townsville } \\
2 \text { Weipa, Bowen } \\
3 \text { Erub Is. } \\
4 \text { Thursday, Moa, Yam, and Ugar islands } \\
5 \text { Saibai and Coconut islands }\end{array}$ & $\begin{array}{c}0.554 \\
(0.001)\end{array}$ & $-0.111^{\mathrm{NS}}$ & $\begin{array}{c}0.504 \\
(0.000)\end{array}$ & 55 & -5 & 50 \\
\hline
\end{tabular}


Cite as: Haig JA, Connolly RM, Hughes JM (2013) Sympatric seagrass shrimp show similar structure and selection along the seashore: a comparison of two cryptic Phycomenes zostericola lineages. Marine Ecology 34:30-42

\section{DISCUSSION}

The two Phycomenes zostericola lineages were morphologically indistinguishable. In the description of P. zostericola (Bruce 2008), some morphological variation was observed between two ovigerous female specimens caught in Moreton Bay, southeast Queensland; Bruce concluded that either substantial variation occurs within species, or, a second taxon was involved. In this study, all 111 specimens of $P$. zostericola sampled from southeast Queensland belonged to the L1; lending support to Bruce's (2008) first possibility of high within-species morphological variation. In sites where the two lineages occurred sympatrically L1 was always more abundant, which may either suggest low numbers of L2 or a sampling bias towards the capture of L1. In alpheid shrimp, sympatric sister species occupy the same habitat type, though patches were dominated by either one or the other sister taxa (Mathews et al. 2002). Further research is required to determine if microhabitat and resource partitioning is occurring between the two lineages, and if this has led to reproductive isolation.

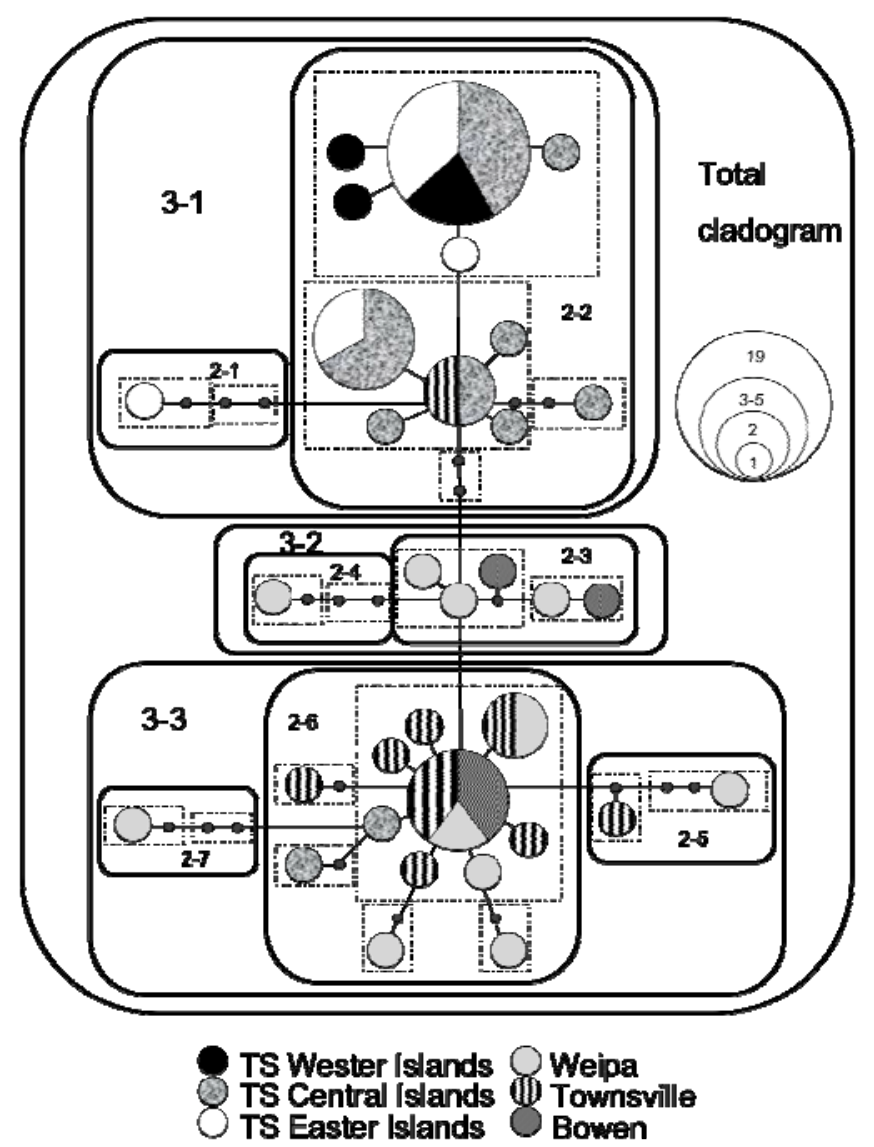

Figure 3. Nested parsimony network for 32 Phycomenes zostericola L2 haplotypes, computed by TCS using $590 \mathrm{bp}$ of the cytochrome oxidase subunit I (COI) gene with $95 \%$ confidence interval. The circle size indicates number of individuals sharing a haplotype; shade or pattern indicates sample location. Connecting bars indicate one base pair mutation between haplotypes and black circles indicate additional base pair mutations. Nesting levels are boxed into clade levels one (broken lines) to four (total cladogram). TS (Torres Strait) Wester Islands: Moa and Thursday islands; TS Central Islands: Saibai, Coconut and Yam islands; TS Easter Islands: Ugar and Erub islands. 
Cite as: Haig JA, Connolly RM, Hughes JM (2013) Sympatric seagrass shrimp show similar structure and selection along the seashore: a comparison of two cryptic Phycomenes zostericola lineages. Marine Ecology 34:30-42

\section{Cryptic diversity}

The deep divergence between the two P. zostericola lineages $(5.6 \% \pm 1)$ is estimated to have occurred during the Pliocene, approximately 3.2-4.6 Ma. The depth of the mitochondrial divergence between the two P. zostericola lineages suggests speciation (Knowlton and Weigt 1998). However, results from nuclear loci failed to reveal if the two divergent lineages were reproductively isolated. Evidence of mitochondrial divergences in other invertebrate species suggests that the divergence observed in P. zostericola is well within the range of that observed for sibling species. For example, reproductive isolation was observed in the freshwater shrimp Paratya australiensis (Cook et al. 2006) and marine snapping shrimp Alpheus armillatus (Mathews et al. 2002) with less than 5\% mitochondrial sequence divergence. Further, mitochondrial divergences of between $2 \%$ and $12 \%$ are congruent with species delineation for sand prawns (Teske et al. 2009); insects (Monaghan et al. 2005; Pons et al. 2006); gastropods (Duda et al. 2008) and echinoderms (Boissin et al. 2008). The divergence between the two $P$. zostericola lineages is recent on an evolutionary timescale and does not yet display variation among the highly conserved and slow evolving nuclear genes trialled during this study.

Table 4. Results of neutrality tests, Tajima's $D$ and Fu's $F_{\mathrm{S}}$ and parameters of the mismatch distribution for three-step clades from a nested clade phylogeographic analysis (NCPA) of Phycomenes zostericola L2 populations from Queensland. Mismatch parameters are: time as scaled by mutation (tau) and time since expansion $(\mathrm{t})$ calculated using the $1.4 \% \mathrm{Myr}^{-1}$ mutation rate. Harpending's raggedness index (Hri) was also applied to mismatch data. Probability values (P) or upper and lower bounds of the $95 \%$ confidence intervals are in parentheses.

\begin{tabular}{lccccc}
\hline Population & Tajima's $D$ & Fu's $F_{\mathrm{S}}$ & Tau & $\mathrm{t}$ (years) & Hri \\
\hline Clade 3-1 & -1.80 & -6.78 & 0.135 & 16300 & 0.046 \\
& $(0.011)$ & $(0.000)$ & $(0-0.506)$ & $(0-61300)$ & $(1.000)$ \\
Clade 3-3 & -2.06 & -10.14 & 1.689 & 204500 & 0.041 \\
& $(0.006)$ & $(0.000)$ & $(0.508-4.639)$ & $(61500-561600)$ & $(0.602)$ \\
\hline
\end{tabular}


Cite as: Haig JA, Connolly RM, Hughes JM (2013) Sympatric seagrass shrimp show similar structure and selection along the seashore: a comparison of two cryptic Phycomenes zostericola lineages. Marine Ecology 34:30-42

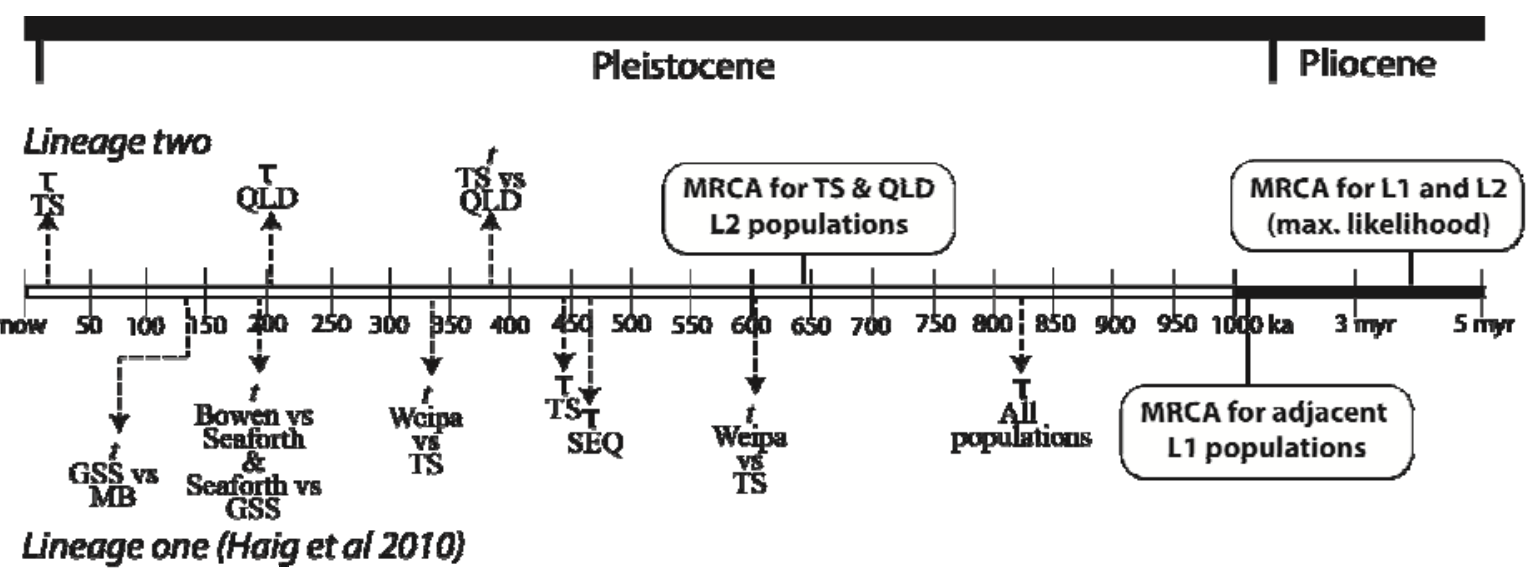

Figure 4. Time line in thousands to millions of years, showing Pleistocene and Pliocene epochs adjacent to the summarised results of maximum likelihood analysis, neutrality tests and coalescent analysis for Phycomenes zostericola L1 (below) and L2 (above). GSS, Great Sandy Strait populations;

MB, Moreton Bay populations; SEQ, south east Queensland populations; $\tau$, time of clade demographic expansion; $t$, time of population coalescence, MRCA, time of most recent common ancestor between either adjacent populations within a lineage or between mitochondrial lineages; TS,

Torres Strait populations; QLD, Queensland populations.

\section{Secondary contact for two divergence lineages}

P. zostericola occur in seagrass meadows (predominantly Zostera muelleri - formerly known as Z. capricorni) from northern Western Australia to New South Wales (Bruce 2008). A comprehensive phylogeographic study of $P$. zostericola L1 can be found in Haig et al. (2010). Both P. zostericola lineages were sympatric in the north (from Weipa to Bowen); but along the Queensland coast only L1 was caught in seagrasses south of Bowen. Any number of scenarios may have lead to the current geographical distribution of the two lineages (Hellberg 1998; Barber et al. 2000; Mathews et al. 2002; Mathews 2007). Whilst it is possible that the most recent common ancestor of the two lineages was an Australian resident there is greater evidence supporting the hypothesis that Queensland is the location for post divergence secondary contact between the two cryptic $P$. zostericola lineages. The data suggest that L1 arrived much earlier than L2; L1 populations coalesce around 1 Ma whereas L2 populations appear to have coalesced more recently (Fig. 4). Further, demographic changes evident from neutrality testing shows L2 with a much more recent history along the Queensland coast compared to L1. Such data for each P. zostericola lineage supports the hypothesis that L1 arrived to north-eastern Australia first and populations expanded prior to the subsequent arrival and expansion of L2 populations. Under this scenario L2 populations were not capable or are yet to experience environmental conditions suitable for a southern range expansion. Further investigation is required to determine if L1 has a greater capacity for dispersal and colonisation or has evolutionary adaptations for cooler southern waters. Sympatric sister pairs of the snapping shrimp Alpheus angulatus and A. armillatus diverged subsequent to the closure of the Isthmus of Panama and are currently in secondary contact (Mathews et al. 2002). Although sibling Alpheus spp. occupy similar microhabitats they exhibit patterns of habitat partitioning suggesting that sympatry and niche competition in 
Cite as: Haig JA, Connolly RM, Hughes JM (2013) Sympatric seagrass shrimp show similar structure and selection along the seashore: a comparison of two cryptic Phycomenes

zostericola lineages. Marine Ecology 34:30-42

these two recently diverged species has selected for high levels of behavioural incompatibility (Mathews et al. 2002). P. zostericola lineages are similar, in that they also occupy the same microhabitat; whether they use spatial or biological resource partitioning or exhibit competitive behaviours is not known and would make a very interesting study.

\section{Demographic differences and similar phylogeographic structure}

The two $P$. zostericola lineages display vastly different demographic histories despite having similar intraspecific genetic structure. L2 had slightly less variation $(\mathrm{h}=0.89)$ and a more recent history $(\tau=0.14$ and 1.69) than that of $\mathrm{L} 1(\mathrm{~h}=0.96, \tau=3.8$ and 6.8 Haig et al. 2010). Both lineages shared a large population size, very little gene exchange between regions and high within and among population diversity. The regional structuring between Torres Strait islands and Queensland populations was also similar, observed in the Nested Clade Phylogeographic Analysis and supported by analyses of molecular variance (AMOVA and SAMOVA). The pair wise $F_{\text {ST }}$ values for L2 between Torres Strait and Queensland sites ( $F_{\text {ST }}$ 0.1-0.6) were slightly higher than those observed in L1 (FST 0.1-0.4 Haig et al. 2010), however, the same pattern of divergence between the two regions was evident. An isolationby-distance effect was confirmed using a Mantel test. However, as no L2 individuals were caught between Torres Strait and Townsville it is difficult to determine if the isolation is a result of divergent onshore currents at $15^{\circ} \mathrm{S}$ or the effects of vast and rapid sea level fluctuations across a shallow, narrow stretch of continental shelf throughout the Pleistocene (see Haig et al., 2010). Sea level fluctuations separated marine populations east and west of Torres Straits and exposed most of the north Queensland continental shelf (Poore 1994). Such sea level fluctuations during the Pleistocene were thought responsible for the morphological divergence among marine sponges (Hooper and Ekins 2004) and the genetic divergence within species of portunid crab (Scylla serrata, Gopurenko and Hughes 2002), penaeid prawn (Penaeus monodon, Benzie et al. 1992), asteroid (Linckia laevigata, Williams and Benzie 1997), and estuarine fish (Lates calcarifer, Chenoweth et al. 1998). Both P. zostericola lineages show significant divergent structure between Queensland and Torres Strait populations, indicating a source population for Torres Strait exists outside Queensland waters, possibly in either the Arafura or Coral Seas. Further sampling from both east (in the Coral Sea) and west (Papua New Guinea, Arafura Sea and northern Australia) is necessary to determine not only the potential source of $P$. zostericola populations but also the location of the divergence between the two lineages.

\section{Populations shaped by changing sea levels}

Both $P$. zostericola lineages experienced population expansions prior to the last glacial maximum (Haig et al. 2010). Data for L2 describes two population expansions; both evident in the network as star-like phylogenies (Slatkin and Hudson 1991). Neutrality tests date the expansions of Torres Strait island populations (clade 3-1) at 16 ka and Queensland populations (clade 3-3) at 204 ka. Population expansions coincide with high sea level periods (sea levels estimated from environmental peaks in oxygen isotopesLisiecki and Raymo 2005). The demographic expansion of Torres Strait L2 populations ( 16 ka) was probably facilitated by a rising sea level and a corresponding increase in available seagrass 
Cite as: Haig JA, Connolly RM, Hughes JM (2013) Sympatric seagrass shrimp show similar structure and selection along the seashore: a comparison of two cryptic Phycomenes zostericola lineages. Marine Ecology 34:30-42

habitat after the last low sea level stand; which left Torres Strait completely exposed approximately $18 \mathrm{ka}$ (Larcombe et al. 1995). The apparent expansion and persistence of Queensland populations (> $204 \mathrm{ka}$ ) throughout periods of lowered sea level strongly suggests that seagrass refugia were present along the central Queensland coastlines.

\section{Evidence for latitudinal selection}

The MyHC gene has proven useful in other phylogeographic studies on caridean shrimp (Williams et al. 2002). In this study the MyHC showed only a single nucleotide polymorphism in both lineages, which was not enough variation to either support or contradict the mitochondrial data. In both lineages the northern populations were fixed for adenine and the southern populations for cytosine. There are two plausible explanations for non-random geographic distribution of MyHC alleles. First, the nuclear mutation is under heavy selection pressure in each geographical region; in which case the mutation either predates the mitochondrial divergence or has occurred recently and independently in both mitochondrial lineages. The second explanation is that the pattern occurred by chance. The myosin heavy chain (MyHC) gene is a protein-coding gene responsible for the development and function of muscle fibres (Mogami et al. 1986); so a mutation may alter an individual's physical aptitude for movement, for example, to escape from predators. The MyHC gene is a useful indicator of temperature adjustment by populations of fish (Vornanen 1994; Liang et al. 2007) and gammarid amphipods (Rock et al. 2009), which both display different MyHC isoforms under different environmental temperature conditions. The early results for $P$. zostericola populations suggest an influence of latitudinal temperature gradients, presenting an exciting opportunity for ocean temperature based research.

\section{CONCLUSION}

Little is understood about broad-scale historical connectivity or cryptic diversity among seagrass fauna. The demographic response to sea level change and habitat fragmentation is variable among the cryptic populations of Phycomenes. The results from the nuclear gene describe two lineages of shrimp both responding to selective pressure in a latitudinal pattern. Included in climate change predictions are a dubious future for seagrass habitats and communities. There is an increasing and immediate need for a better understanding of seagrass species connectivity on both ecological and evolutionary scales. This study provides a valuable starting point to a better understanding of history, connectivity and structure for two permanent and abundant seagrass inhabitants.

\section{ACKNOWLEDGEMENTS}

Financial support for this work came from the Queensland Government Smart State Research Award and Griffith University. We are grateful to the following researchers for assistance in obtaining samples: Ian and Malcolm McCollum (Cape York Marine Advisory Group), Helen Taylor and Michael Rasheed (DEEDI, Cairns), David Kopelke (Boyne Island Environmental Education Centre, Gladstone), James Webley, Ben Cook (Griffith University) and Simon Mehrtens. We are indebted to Olaf Meynecke (Griffith University) for sampling Torres Strait, and Sandy Bruce (Queensland Museum) for invaluable assistance with P. zostericola 
Cite as: Haig JA, Connolly RM, Hughes JM (2013) Sympatric seagrass shrimp show similar structure and selection along the seashore: a comparison of two cryptic Phycomenes zostericola lineages. Marine Ecology 34:30-42

identification and mulitple discussions on Pontoniine taxonomy and biology.

\section{REFERENCES}

Avise, J.C. (2000). Phylogeography: the history and formation of species. Harvard University Press, Cambridge, Massachusetts: 135-208 pp.

Avise, J.C., J. Arnold, et al. (1987) Intraspecific phylogeography: the mitochondrial DNA bridge between population genetics and systematics. Annual Review of Ecology and Systematics, 18, 489-522.

Barber, P.H., S.R. Palumbi, et al. (2000) A marine Wallace's line? Nature, 406, 692-693. Benzie, J.A.H., E. Ballment, et al. (2002) Mitochondrial DNA variation in Indo-Pacific populations of the giant tiger prawn, Penaeus monodon. Molecular Ecology, 11, 2553-2569. Benzie, J.A.H., S. Frusher, et al. (1992) Geographical variation in allozyme frequencies of populations of Penaeus monodon (Crustacea:Decapoda) in Australia. Australian Journal of Marine and Freshwater Research, 43, 715-725.

Boissin, E., J.P. Feral, et al. (2008) Defining reproductively isolated units in a cryptic and syntopic species complex using mitochondrial and nuclear markers: the brooding brittle star, Amphipholis squamata (Ophiuroidea). Molecular Ecology, 17, 1732-1744.

Bruce, A.J. (2008) Phycomenes zostericola gen. nov, sp. nov., a new pontoniine shrimp (Crustacea: Decapoda: Palaemonidae) from Moreton Bay, Queensland. In: P.J.F. Davie \& J.A. Phillips (Eds). Proceedings of the Thirteenth International Marine Biological Workshop, The Marine Fauna and Flora of Moreton Bay, Queensland. Memoirs of the Queensland Museum - Nature. Queensland Museum, Brisbane: 219-232.

Burton, R.S. (1997) Genetic evidence for long-term persistence of marine invertebrate populations in an ephemeral environment. Evolution, 51, 993-998.

Chenoweth, S.F., J.M. Hughes, et al. (1998) When oceans meet: a teleost shows secondary intergradation at an Indian-Pacific interface. Proceedings of the Royal Society of London. B., 265, 415-420.

Clement, M., D. Posada, et al. (2000) TCS: a computer program to estimate gene genealogies. Molecular Ecology, 9, 1657-1659.

Connolly, R.M. (2009) Seagrass. In: E.S. Poloczanska, A.J. Hobday \& A.J. Richardson (Eds). A Marine Climate Change Impacts and Adaptation Report Card for Australia 2009. National Climate Change Adaptation Research Facility.

Cook, B.D., A.M. Baker, et al. (2006) Biogeographic history of an Australian freshwater shrimp, Paratya australiensis (Atyidae): the role life history transition in phylogeographic diversification. Molecular Ecology, 15, 1083-1093.

Cook, B.D., C.M. Pringle, et al. (2008) Molecular evidence for sequential colonization and taxon cycling in freshwater decapod shrimps on a Caribbean island. Molecular Ecology, 17, 1066-1075.

Crandall, E.D., M.E. Jones, et al. (2008) Comparative phylogeography of two seastars and their ectosymbionts within the Coral Triangle. Molecular Ecology, 17, 5276-5290.

De Grave, S. (1999) Caridean shrimps (Crustacea, Decapoda) from seagrass habitats in Hansa Bay, Papua New Guinea. Beaufortia, 49(3), 19-27. 
Cite as: Haig JA, Connolly RM, Hughes JM (2013) Sympatric seagrass shrimp show similar structure and selection along the seashore: a comparison of two cryptic Phycomenes zostericola lineages. Marine Ecology 34:30-42

Doyle, J.J., J.L. Doyle (1987) A rapid DNA isolation procedure for small quantities of fresh leaf tissue. Phytochemistry Bulletin, 19, 11-15.

Duda, T., F, Jr., M.B. Bolin, et al. (2008) Hidden diversity in a hyperdiverse gastropod genus: Discovery of previoulsy unidentified members of a Conus species complex. Molecular Phylogenetics and Evolution, 49, 867-876.

Dupanloup, I., S. Schneider, et al. (2002) A simulated annealing approach to define the genetic structure of populations. Molecular Ecology, 11(12), 2571-2581.

Excoffier, L. (2004) Patterns of DNA sequence diversity and genetic structure after a range expansion: lessons from the infinite-island model. Molecular Ecology, 13(4), 853-864.

Excoffier, L., G. Laval, et al. (2005) Arlequin ver. 3.0: An integrated software package for population genetics data analysis. Evolutionary Bioinformatics Online, 1, 47-50.

Excoffier, L., P.E. Smouse, et al. (1992) Analysis of molecular variance inferred from metric distances among DNA haplotypes: application to human mitochondrial DNA restriction data. Genetics, 131, 479-491.

Fu, Y.X. (1997) Statistical tests of neutrality of mutations against population growth, hitchhiking and background selection. Genetics, 147, 915-925.

Galloway, R.W., E.M. Kemp (1981) Late Cainozoic environments in Australia. In: A. Keast (Ed). Ecological Biogeography of Australia. Dr. W. Junk bv Publishers, The Hague: 53-77. Gopurenko, D., J.M. Hughes (2002) Regional patterns of genetic structure among Australian populations of the mud crab, Scylla serrata (Crustacea: Decapoda): evidence from mitochondrial DNA. Marine and Freshwater Research, 53, 849-857.

Haig, J.A., R.M. Connolly, et al. (2010) Little shrimp left on the shelf: the roles that sea-level change, ocean currents and continental shelf width play in the genetic connectivity of a seagrass-associated species. Journal of Biogeography, 37, 1570-1583.

Harpending, R.C. (1994) Signature of ancient population growth in a low-resolution mitochondrial DNA mismatch distribution. Human Biology, 66, 591-600.

Heck, K.L., Jr., J.F. Valentine, et al. (2003) Plant-animal interactions in seagrass-dominated ecosystems: a review and a prospectus. Gulf of Mexico Science, 21(1), 112.

Hellberg, M.E. (1998) Sympatric sea shells along the sea's shore: the geography of speciation in the marine gastropod Tegula. Evolution, 52, 1311-1324.

Hey, J., R. Nielsen (2004) Mulitlocus methods for estimating population sizes, migration rates and divergence time, with applications to the divergence of Drosophila pseudoobscura and D. persimilis. Genetics, 167, 747-760.

Hilbish, T.J. (1985) Demographic and temporal structure of an allele frequency cline in the mussel Mytilus edulis. Marine Biology, 86, 163-171.

Hooper, J.N.A., M. Ekins (2004). Collation and validation of museum collection databases related to the distribution of marine sponges in northern Australia. Technical Reports of the Queensland Museum number 002. Queensland Museum, Brisbane, Queensland: 1-224 pp. Hughes, J.M., S.E. Bunn, et al. (1995) Genetic differentiation and dispersal among populations of Paratya australiensis (Atyidae) in rainforest streams in southeast Queensland, Australia. Journal of the North American Benthological Society, 14(1), 158-173. 
Cite as: Haig JA, Connolly RM, Hughes JM (2013) Sympatric seagrass shrimp show similar structure and selection along the seashore: a comparison of two cryptic Phycomenes zostericola lineages. Marine Ecology 34:30-42

Hurwood, D.A., J.M. Hughes (2001) Nested clade analysis of the freshwater shrimp, Caridina zebra (Decapoda: Atyidae), from north-eastern Australia. Molecular Ecology, 10, 113-125.

Huson, D.H., D.C. Richter, et al. (2007) Dendroscope - An interactive viewer for large phylogenetic trees. BMC Bioinformatics, 8, 460.

Ji, Y.-J., D.-x. Zhang, et al. (2003) Evolutionary conservation and versatility of a new set of primers for amplifying the ribosomal internal transcribed spacer regions in insects and other invertebrates. Molecular Ecology Notes, 3, 581-585.

Knowlton, N. (1993) Sibling species in the sea. Annual Review of Ecology and Systematics, 24, 189-216.

Knowlton, N., L.A. Weigt (1998) New dates and new rates of divergence across the isthmus of Panama. Proceedings of the Royal Society of London. B., 265, 2257-2263.

Larcombe, P., R.M. Carter, et al. (1995) New evidence for episodic post-glacial sea-level rise, central Great Barrier Reef, Australia. Marine Geology, 127, 1-44.

Lavery, S., C. Moritz, et al. (1996) Indo-Pacific population structure and evolutionary history of the coconut crab Birgus latro. Molecular Ecology, 5, 557-570.

Liang, C.-S., A. Kobiyama, et al. (2007) Fast skeletal muscle myosin heavy chain gene cluster of medaka Oryzias latipes enrolled in temperature adaptation. Physiological Genomics, 29, 201-214.

Lisiecki, L., M.E. Raymo (2005) A Pliocene-Pleistocene stack of 57 globally distributed benthic $\delta^{18}$ O records. Paleoceanography, 20(PA1003), 1-17.

Mathews, L.M. (2007) Evidence for restricted gene flow over small spatial scales in a marine snapping shrimp Alpheus angulosus. Marine Biology, 152, 645-655.

Mathews, L.M., C.D. Schubart, et al. (2002) Genetic, ecological, and behavioural divergence between two sibling snapping shrimp species (Crustacea: Decapoda: Alpheus). Molecular Ecology, 11, 1427-1437.

Miller, M., M. Holder, et al. (2009) The CIPRES Portals: Archived by WebCite (r) at http://www.webcitation.org/5imQ1JeQa.

Mitsuhashi, M., Y.W. Sin, et al. (2007) Systematic status of the caridean families Gnathophyllidae Dana and Hymenoceridae Ortmann (Crustacea: Decapoda): a preliminary examination based on nuclear rDNA sequences. Invertebrate Systematics, 21, 613-622. Mogami, K., P.T. O'Donnell, et al. (1986) Mutations of the Drosophila myosin heavy-chain gene: effects on transcription, myosin accumulation, and muscle function. Proceedings of the National Academy of Sciences (USA), 83(5), 1393-1397.

Monaghan, M.T., M. Balke, et al. (2005) DNA-based species delineation in tropical beetles using mitochondrial and nuclear markers. Philosophical Transactions of the Royal Society B: Biological Sciences, 360, 1925-1933.

Morrison, C.L., R. Rios, et al. (2004) Phylogenetic evidence for an ancient rapid radiation of Caribbean sponge-dwelling snapping shrimps (Synalpheus). Molecular Phylogenetics and Evolution, 30, 563-581.

Narum, S.R. (2006) Beyond Bonferroni: less conservative analyses for conservation genetics. Conservation Genetics, 7, 783-787. 
Cite as: Haig JA, Connolly RM, Hughes JM (2013) Sympatric seagrass shrimp show similar structure and selection along the seashore: a comparison of two cryptic Phycomenes zostericola lineages. Marine Ecology 34:30-42

Orth, R.J., T.J.B. Carruthers, et al. (2006) A global crisis for seagrass ecosystems. Bioscience, 56(12), 987-996.

Petit, R.J. (2008) The coup de grâce for the nested clade phylogeographic analysis? Molecular Ecology, 17(2), 516-518.

Pons, J., T. Barraclough, et al. (2006) Sequence-based species delimitation for the DNA taxonomy of undescribed insects. Systematic Biology, 55(4), 595-609.

Poore, G.C.B. (1994) Marine biogeography of Australia. In: L.S. Hammond \& R.N. Synnot (Eds). Marine Biology. Longman Cheshire, Melbourne: 189-212.

Porter, M.L., M. Pérez-Losada, et al. (2005) Model-based multi-locus estimation of decapod phylogeny and divergence times. Molecular Phylogenetics and Evolution, 37, 355-369.

Posada, D., K.A. Crandall (2001) Intraspecifiic gene genealogies: trees grafting into networks. Trends in Ecology and Evolution, 16(1), 37-45.

Posada, D., K.A. Crandall, et al. (2000) Geodis: a program for the cladistic nested analysis of the geographical distribution of genetic haplotypes. Molecular Ecology, 9, 487-488.

Rock, J., J.L. Magnay, et al. (2009) Linking functional molecular variation with environmental gradients: Myosin gene diversity in a crustacean broadly distributed across variable thermal environments. Gene 437, 60-70.

Rozas, J., J.C. Sánchez-DelBarrio, et al. (2003) DnaSP, DNA polymorphism analyses by the coalescent and other methods. Bioinformatics, 19, 2496-2497.

Schneider, S., L. Excoffier (1999) Estimation of demographic parameters from the distribution of pairwise differences when the mutation rates vary among sites: Application to human mitochondrial DNA. Genetics, 152, 1079-1089.

Slatkin, M., R.R. Hudson (1991) Pairwise comparisons of mitochondrial DNA sequences in stable and exponentially growing populations. Genetics, 129, 555-562.

Song, H., J.E. Buhay, et al. (2008) Many species in one: DNA barcoding overestimates the number of species when nuclear mitochondrial pseudogenes are coamplified. Proceedings of the National Academy of Sciences (USA), 105(36), 13486-13491.

Stamatakis, A. (2006) RAxML-VI-HPC: Maximum Likelihood-based Phylogenetic Analyses with Thousands of Taxa and Mixed

Models. Bioinformatics, 22(21), 2688-2690.

Stamatakis, A., P. Hoover, et al. (2008) A Rapid Bootstrap Algorithm for the RAxML WebServers. Systematic Biology, 75(5), 758-771.

Stamatakis, A., M. Ott, et al. (2005) RAxML-OMP: An Efficient Program for Phylogenetic Inference on SMPs. Proceedings of 8th International Conference on Parallel Computing Technologies (PaCT2005). Lecture Notes in Computer Science. Springer Verlag: 288-302. Tajima, F. (1989) Statistical method for testing the neutral mutation hypothesis by DNA polymorphism. Genetics, 123, 585-595.

Tamura, K., J. Dudley, et al. (2007) MEGA4: Molecular Evolutionary Genetics Analysis (MEGA) software version 4.0. Molecular Biology and Evolution, 24, 1596-1599.

Templeton, A.R. (2008) Nested clade analysis: an extensively validated method for strong phylogeographic inference. Molecular Ecology, 17, 1877-1880. 
Cite as: Haig JA, Connolly RM, Hughes JM (2013) Sympatric seagrass shrimp show similar structure and selection along the seashore: a comparison of two cryptic Phycomenes zostericola lineages. Marine Ecology 34:30-42

Templeton, A.R., E. Bowerwinkle, et al. (1987) A cladistic analysis of phenotypic associations with haplotypes inferred from restriction endonuclease mapping. I. Basic theory and an analysis of alcohol dehydrogenase activity in Drosophila. Genetics, 117, 343-351. Templeton, A.R., E. Routman, et al. (1995) Separating population structure from population history: a cladistic analysis of the geographical distribution of mitochondrial DNA haplotypes in the tiger salamander, Ambystoma tigrinum. Genetics, 140, 767-782.

Templeton, A.R., C.F. Sing (1993) A cladistic analysis of phenotypic associations with haplotypes inferred from restriction endonuclease mapping. IV. Nested analyses with cladogram uncertainty and recombination. Genetics, 134 659-669.

Teske, P.R., P.W. Froneman, et al. (2007) Phylogeographic structure of the caridean shrimp Palaemon peringueyi in South Africa: further evidence for intraspecific genetic units associated with marine biogeographic provinces. African Journal of Marine Science, 29(2), 253-258.

Teske, P.R., H. Winker, et al. (2009) A tropical/subtropical biogeographic disjunction in the southeastern Africa separates two evolutionary significant units of an estuarine prawn. Marine Biology, 156, 1265-1275.

Vornanen, M. (1994) Seasonal and temperature-induced changes in myosin heavy chain composition of crucian carp hearts. American Journal of Physiology.Regulatory, Integrative and Comparative Physiology, 267, 1567-1573.

Wadley, V.A. (1978) A checklist and illustrated key to the epibenthic shrimps (Decapoda: Natantia) of Moreton Bay, Queensland. Report No. 99. Commonwealth Scientific and Industrial Research Organization. Division of Fisheries and Oceanography., Sydney, New South Wales: 1-23.

Wilding, C.S., R.K. Butlin, et al. (2001) Differential gene exchange between parapatric morphs of Littorina saxatilis detected using AFLP markers. Journal of Evolutionary Biology, 14, 611-619.

Williams, S.T., J.A.H. Benzie (1997) Indo-west Pacific patterns of genetic differentiation in the high-dispersal starfish Linckia laevigata. Molecular Ecology, 6, 559-573.

Williams, S.T., J. Jara, et al. (2002) The marine Indo-West Pacific break: contrasting the resolving power of mitochondrial and nuclear genes. Integrative and Comparative Biology, 42, 941-952.

Williams, S.T., N. Knowlton, et al. (2001) Evidence for three major clades within the snapping shrimp genus Alpheus inferred from nuclear and mitochondrial gene sequence data. Molecular Phylogenetics and Evolution, 20(3), 375-389. 